\title{
Rancang Bangun Purwarupa Pendeteksi Berat Muatan Bus Transjakarta Menggunakan Metode Incremental Berbasis Mikrokontroler Arduino Uno
}

\author{
Yudi Irawan Chandra ${ }^{1}$, Kosdiana ${ }^{2}$

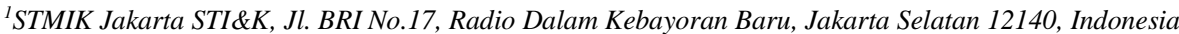 \\ Iyirawanc@gmail.com, ${ }^{2}$ kosdiana.put@gmail.com
}

\section{INFORMASI ARTIKEL}

Sejarah Artikel:

Diterima Redaksi: 20-02-2020

Revisi Akhir: 13-04-2020

Diterbitkan Online: 14-04-2020

\section{KATA KUNCI}

\section{Arduino Uno.}

Deteksi Berat Bus,

Metode Incremental,

Purwarupa

KORESPONDENSI

Telepon: +628128094249

E-mail: yirawanc@gmail.com

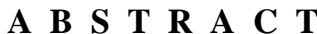

At present transportation is a common thing for the citizens of the City of Jakarta. Handling by the Jakarta City government continues to be pursued. One way to do this can be to construct a busway path. The development of this course is expected to overcome the issue of blockage within the city of Jakarta. An incremental model is a system development model in software engineering based on software requirements that are broken down into functions or parts so that the development model is phased in. on the other hand there is interpreting the incremental model as an improvement of the waterfall model and as a standard topdown approach. Using this model is expected to produce software that functions quickly and earlier during the software life cycle, is more flexible and cheaper to change the scope and requirements, thereby reducing initial shipping costs. Furthermore this model is easier to do testing and debug during smaller iterations. The development of life and technology at this time is felt more quickly and demands change in various sectors. Very rapid technological advances allow for various businesses to provide convenience and comfort for humans. One effort to provide convenience and comfort is through the development of load weight detection system design on Transjakarta buses. Adding Arduino as a "brain" and detecting the weight of this load is more practical but very useful for humans and the feasibility of Transjakarta. If the detector is overloaded, a buzzer will sound that has detected excessive overload.

\section{PENDAHULUAN}

Transportasi merupakan suatu yang penting bagi masyarakat yang tinggal di Jakarta sehingga salah satu cara yang dilakukan untuk meningkatkan pelayanan adalah pembangunan jalur busway. Pembangunan jalur ini semestinya dapat menanggulangi masalah kemacetan di kota Jakarta. Salah satu cara untuk meningkatkan keamanan penumpang adalah dengan mengembangkan pendeteksi berat muatan menggunakan sensor berat yang di lengkapi buzzer sebagai alarm peringatan. Oleh karena itu, perlunya tambahan sistem keamanan yang lebih baik bagi transportasi Transjakarta.

Dengan menggunakan Arduino Uno sebagai otak pengendali sistem keamanan ini makin mudah dan praktis tetapi bermanfaat bagi kelayakan Transjakarta, Sensor berat sebagai alat identifikasi berat pada transportasi Transjakarta. Buzzer untuk mengetahui jika kapasitas pada saat Transjakarta melebihi muatan atau peringatan.
Adapun identifikasi masalah pada penelitian ini adalah meningkatkan keamanan transportasi Transjakarta dengan menambahkan sensor berat untuk mengetahui beban berat pada transportasi Transjakarta.

Batasan masalah yang akan dibahas pada penelitian ini adalah merancangan alat, membuat alat, menguji alat, dimana batasan total berat pada penumpang sebesar 2.700 kilogram untuk memberikan kenyamanan atau kelayakan pada Transjakarta. Memanfaatkan beberapa alat yaitu arduino untuk pengendali, sensor berat untuk identifikasi dan buzzer untuk memberikan simbol keamanan pada transportasi busway. Kemudian dilakukan proses penyimpanan data dengan sistem kendali mikrokontroler arduino uno untuk mendeteksi berat.ransjakarta tersebut.

Sehingga pada penelitian ini akan dibuat suatu sistem yang dapat memberikan keamanan tambahan dan membuat sistem untuk menghindari kerusakan dan layak pada transportasi Transjakarta. 


\section{LANDASAN TEORI}

\subsection{Mikrokontroler}

Mikrokontroler adalah suatu alat elektronika digital yang mempunyai masukan dan keluaran serta kendali dengan program yang bisa ditulis dan dihapus secara khusus [1]. berikut:

Mikrokontroler memiliki karakteristik sebagai

a. Memiliki program khusus yang disimpan dalam memori untuk aplikasi tertentu, tidak seperti PC (Personal Computer) yang multi fungsi karena mudahnya memasukkan program. Program mikrokontroler relatif lebih kecil daripada program - program pada PC.

b. Konsumsi daya relatif kecil.

c. Unit I/O yang sederhana, misalnya LCD, LED, Sensor

Atmega 328 adalah mikrokontroler buatan Atmel Corporation yang mempunyai arsitektur RISC (Reduce Instruction Set Computer) yang dimana setiap proses eksekusi data lebih cepat dari pada arsitektur CISC (Completed Instruction Set Computer). Mikrokontroler Atmega 328 memiliki arsitektur Harvard, dimana memori untuk kode program dan memori untuk data dipisahkan sehingga dapat memaksimalkan kerja dan parallelism. Berikut konfigurasi pin Atmega 328 dapat dilihat pada gambar 1 .

\begin{tabular}{|c|c|c|c|}
\hline & & & \\
\hline (PCINT14/RESET) PC6 & 1 & 28 & PC5 (ADC5/SCL/PCINT13) \\
\hline (PCINT16/RXD) PD0 [ & 2 & 27 & $\square \mathrm{PC} 4$ (ADC4/SDA/PCINT12) \\
\hline (PCINT17/TXD) PD1 & 3 & 26 & D PC3 (ADC3/PCINT11) \\
\hline (PCINT18/INTO) PD2 & 4 & 25 & 口PC2 (ADC2/PCINT10) \\
\hline (PCINT19/OC2B/INT1) PD3 [ & 5 & 24 & 口PC1 (ADC1/PCINT9) \\
\hline (PCINT20/XCK/T0) PD4 & 6 & 23 & $\square \mathrm{PCO}(\mathrm{ADC} 0 / \mathrm{PCINT} 8)$ \\
\hline $\operatorname{vCC} \square$ & 7 & 22 & PGND \\
\hline GND [ & 8 & 21 & $\square$ AREF \\
\hline (PCINT6/XTAL1/TOSC1) PB6 & 9 & 20 & $\square$ AVCC \\
\hline (PCINT7/XTAL2/TOSC2) PB7 & 10 & 19 & PB5 (SCK/PCINT5) \\
\hline (PCINT21/OCOB/T1) PD5 & 11 & 18 & $\square$ PB4 (MISO/PCINT4) \\
\hline (PCINT22/OCOAAIN0) PD6 & 12 & 17 & $\square$ PB3 (MOSI/OC2A/PCINT3) \\
\hline (PCINT23/AIN1) PD7 & 13 & 16 & $\square \mathrm{PB} 2$ (SS/OC1B/PCINT2) \\
\hline (PCINTO/CLKO/ICP1) PBO & 14 & 15 & P PB1 (OC1A/PCINT1) \\
\hline
\end{tabular}

Gambar 1. Konfigurasi pin Atmega 328[2]

\subsection{Arduino}

Arduino adalah papan pengendali rangkaian elektronik yang bersifat open-source, diturunkan dari wiring platform yang dirancang untuk memudahkan penggunaan elektronik dalam berbagai bidang. Perangkat kerasnya memiliki prosesor Atmel AVR. Peranti ini dapat dimanfaatkan untuk mewujudkan rangkaian elektronik dari yang sederhana hingga yang kompleks. Pengendalian LED, mengontrol helikopter, penggerak servo hingga pengontrolan robot juga dapat di implementasikan dengan penambahan komponen tertentu sesuai apa yang ingin digunakan. Bentuk dari papan Arduino Uno dapat dilihat pada gambar 2.

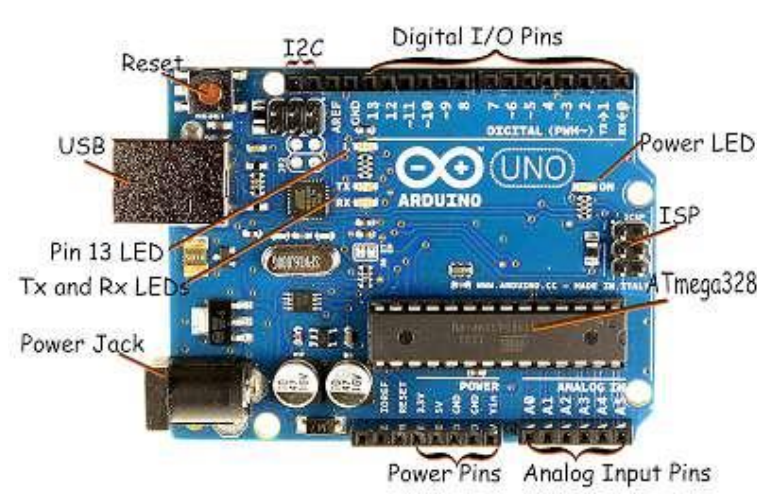

Gambar 2. Arduino Uno Atmega 328 [3]

Arduino Uno dilengkapi dengan static randomaccess memory (SRAM) berukuran $2 \mathrm{~Kb}$ untuk memegang data flash memory berukuran $32 \mathrm{~Kb}$, dan erasable progammable read-only memory (EEPROM) [4].

\subsection{Sensor Berat (Load Cell)}

Sensor load cell merupakan sensor yang dirancang untuk mendeteksi tekanan atau berat sebuah beban, sensor load cell umumnya digunakan sebagai komponen utama pada sistem timbangan digital dan dapat diaplikasikan pada jembatan timbangan yang berfungsi untuk menimbang berat dari truk pengangkut bahan baku, pengukuran yang dilakukan oleh Load Cell menggunakan prinsip tekanan. Untuk contoh fisik seperti terlihat pada gambar 3 [5].

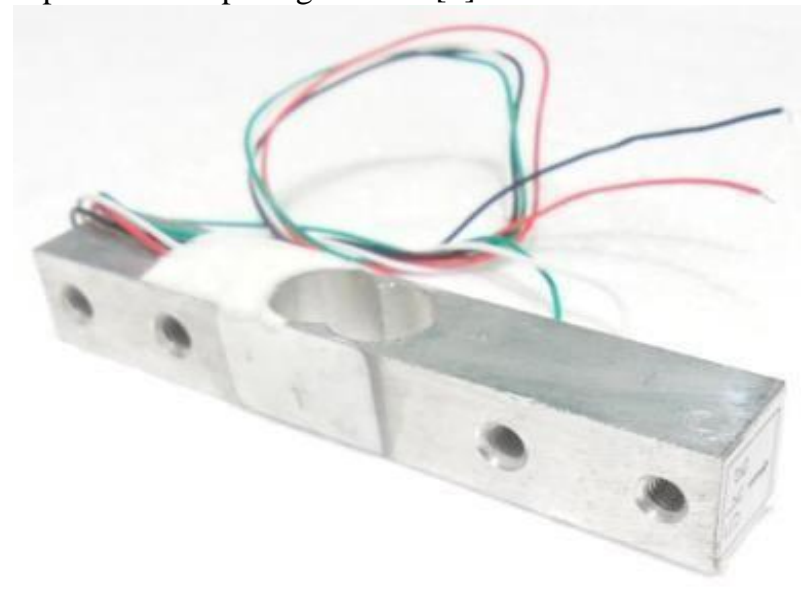

Gambar 3. Bentuk fisik load cell [5]

\subsection{Modul Penguat HX711}

HX711 adalah modul timbangan, yang memiliki prinsip kerja mengkonversi perubahan yang terukur dalam perubahan resistansi dan mengkonversinya ke dalam besaran tegangan melalui rangkaian yang ada. Modul melakukan komunikasi dengan computer/mikrokontroller melalui TTL232. Struktur yang sederhana, mudah dalam penggunaan, hasil yang stabil dan reliable, memiliki sensitivitas tinggi, dan mampu mengukur perubahan dengan cepat. HX711 biasanya digunakan pada bidang aerospace, mekanik, elektrik, kimia, konstruksi, farmasi dan lainnya, digunakan untuk mengukur gaya, gaya tekanan, perpindahan, gaya tarikan, torsi, dan percepatan. Bentuk seperti terlihat pada gambar 4. 


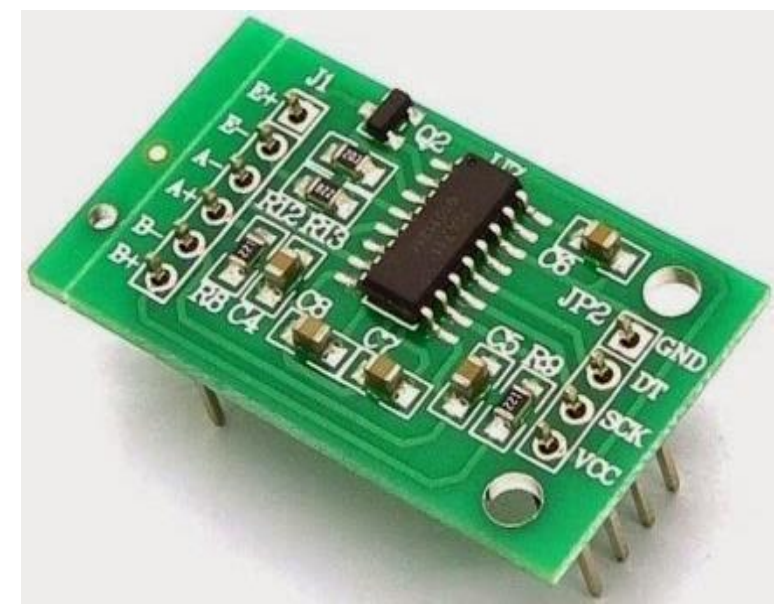

Gambar 4. Modul penguat HX711 [5]

Untuk perhitungan konversi input analog ke digital yang berbentuk heksadesimal dapat digunakan perhitungan seperti pada persamaan (1).

$$
\text { Out }=\frac{\text { input }-(-40)}{80} \times 2^{24}
$$

Contoh:

Out $=\frac{0,3-(-40)}{80} \times 16777216$

Out $=8451522$ heksadesimal

Bilangan heksadesimal diataslah yang kemudian yang dapat diolah mikrokontroler yang kemudian dikonversikan kembali menjadi satuan berat [5].

\subsection{Buzzer}

Buzzer adalah sebuah komponen elektronika yang berfungsi untuk mengubah getaran listrik menjadi getaran suara. Pada dasarnya prinsip kerja buzzer hampir sama dengan loud speaker. [6]

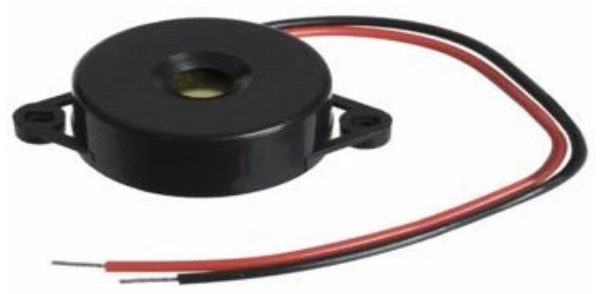

Gambar 5. Buzzer [6]

\subsection{Motor Servo}

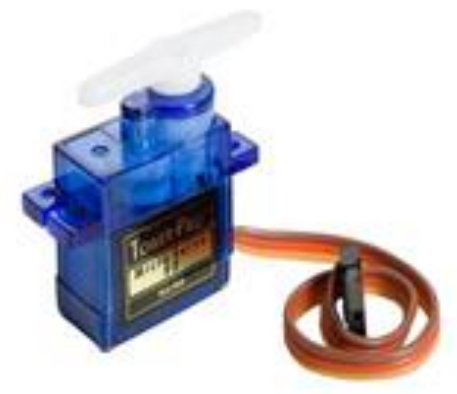

Gambar 6. Motor servo [7]
Motor servo menggunakan sistem umpan balik tertutup, di mana posisi dari motor akan diinformasikan kembali ke rangkaian kontrol yang ada di dalam motor servo. Motor ini terdiri dari sebuah motor DC, serangkaian gear, potensiometer dan rangkaian kontrol. Gambar 6 menunjukkan gambar motor servo [7].

\section{METODOLOGI}

Metodologi perancangan perangkat lunak menggunakan model incremental dengan tahapan: Requirement, Specification, Architecture Design, Code, dan Test. Tahapan dapat dilihat pada Gambar 7.
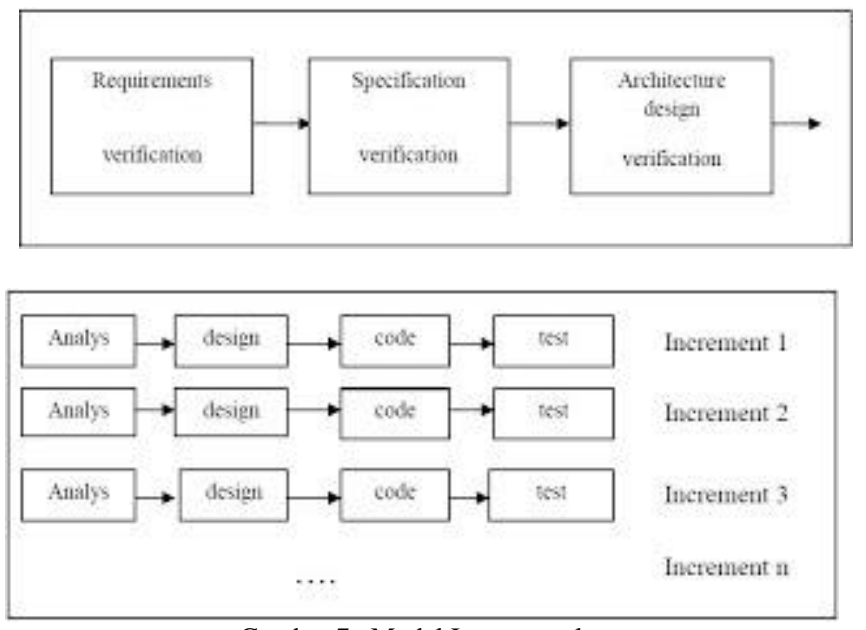

Gambar 7. Model Incremental

\section{HASIL DAN PEMBAHASAN}

Perancangan dan pembuatan alat dikelompokkan menjadi beberapa bagian Diagram blok rangkaian menggambarkan blok input, proses, dan output secara umum. Perancangan rangkaian dan komponen menjelaskan tahapan rancangan bangun alat, komponen yang dibutuhkan beserta fungsi dan rangkaian keseluruhan. Prinsip kerja rangkaian berisi penjabaran proses kerja secara terperinci. Diagram alur program menggambarkan langkah kerja alat berupa diagram. Perancangan program mikrokontroler berisi tahapan pemrograman perangkat lunak.

Pendeteksi berat muatan pada Transjakarta ini menerima masukan dari sensor berat (load cell) lalu akan diproses oleh Arduino Uno dan menghasilkan keluaran berupa kondisi HIGH/LOW yang akan mengaktifkan Buzzer. Arduino Uno bekerja dengan memberikan tegangan $5 \mathrm{~V}$ melalui USB yang di hubungkan pada Komputer. Pada Gambar 8 dapat dilihat cara kerja setiap blok rangkaian yang ada, berikut uraian cara kerjanya:

1. Switch sebagai masukan pilihan menu.

2. Sensor Berat sebagai pendeteksi berat muatan pada Transjakarta.

3. Arduino Uno sebagai pemrosesan dari blok masukan.

4. Buzzer sebagai pemberitahuan bahwa berat pada muatan Transjakarta berlebihan.

5. Motor Servo sebagai membuka pintu pada Transjakarta. 


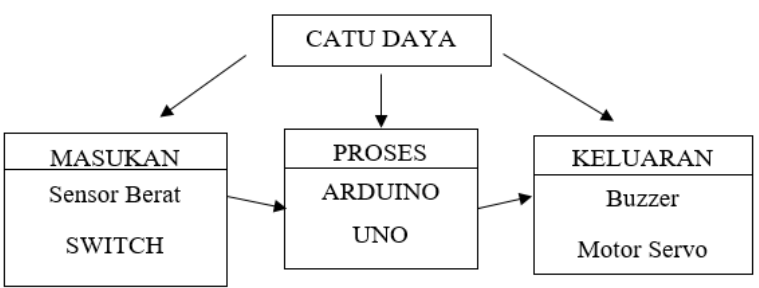

Gambar 8. Diagram Blok Rangkaian

\subsection{Prinsip Kerja Rangkaian}

Pada penelitian ini pembuatan pendeteksi berat muatan pada Transjakarta dibuat dengan memanfaatkan Mikrokontroler Arduino Uno yang digunakan untuk memproses data yang diterima oleh sensor, mikrokontroler juga berfungsi mengendalikan sumber daya maupun komponen yang terhubung pada mikrokontroler agar dapat melakukan pemrosesan dan pengolahan data digital.

Mikrokontroler dapat bekerja dengan menghubungkannya melalui port USB (Universal Serial Bus) sehingga memperoleh tegangan yang diperlukan untuk bekerja sebesar $5-5,5 \mathrm{~V}$. Pada pendeteksi berat muatan pada Transjakarta Data Logging digunakan untuk menjalankan proses penyimpanan data pada memori yang berguna untuk melakukan pengontrolan pada berat muatan sesuai kondisi dari parameter penumpang yang di dapat.

Sensor berat (load cell) kemudian melakukan pendeteksian terhadap keadaan dari berat muatan berdasarkan parameter penumpang yang sedang terjadi pada kondisi tertentu. Pada saat berat muatan pada Transjakarta terdeteksi dalam radius jangkauan sensor maka akan ditampilkan pada buzzer dapat dilakukan proses pemantauan kondisi berat muatan pada saat dilakukannya tindakan pada penumpang.

Switch digunakan sebagai membuka dan menutup pada sistem ini agar data yang diperoleh sesuai dengan keadaan Transjakarta untuk menaikan dan menurunkan penumpang. Sistem ini berjalan secara terhubungnya motor servo agar dapat terbuka dan tertutupnyanya pintu untuk dapat memasukan dan menurunkan penumpang.

\subsection{Rangkaian Keseluruhan}

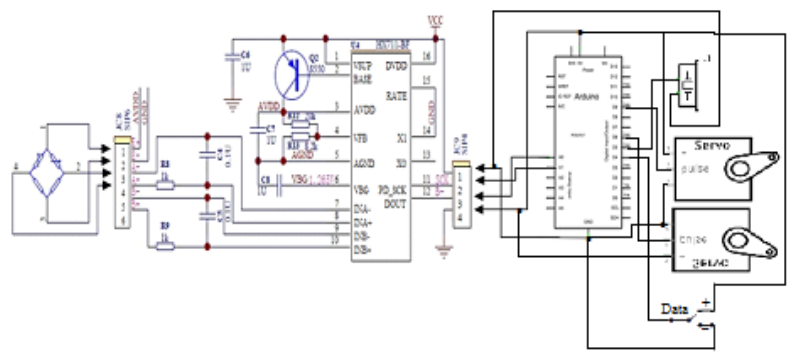

Gambar 9. Skematik Keseluruhan Alat

Rangkaian keseluruhan merupakan rangkaian gabungan dari komponen-komponen yang digunakan pada alat simulasi pendeteksi berat muatan pada Transjakarta. Rangkaian ini bekerja berdasarkan adanya masukan dari modul sensor berat (load cell), dan saklar SPDT kemudian masukan tersebut diproses oleh mikrokontroler Arduino Uno sehingga akan diperoleh hasil dari proses tersebut. Hasil proses yang dilakukan Arduino Uno akan dikirim ke keluaran yaitu buzzer untuk menunjukan jika berat pada muatan Transjakarta, motor servo sebagai membuka dan menutup pintu Transjakarta. Rangkaian keseluruhan dari alat simulasi pendeteksi berat muatan pada Transjakarta dapat dilihat pada gambar 9 .

\subsection{Diagram Alur Program}

Sebelum menyusun suatu program pada mikrokontroler Arduino Uno, langkah pertama yang harus dilakuakan adalah menyusun suatu diagram alur atau flowchart yang akan digunakan sebagai acuan untuk menulis sketch program pada mikrokontroler Arduino Uno. Diagram alur dari alat pendeteksi berat muatan pada Transjakarta dapat dilihat pada gambar 10 .

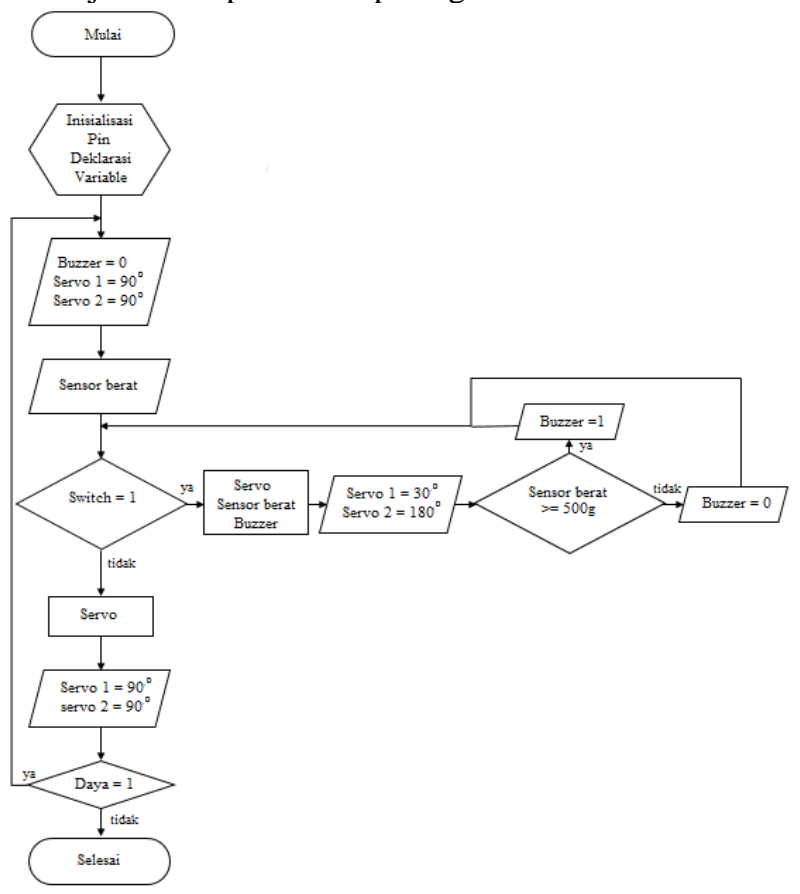

Gambar 10. Diagram alur rangkaian

Pada gambar 10 dapat dijelaskan bahwa alat akan bekerja setelah mendapatkan masukan tegangan, inisialisasi pin dan deklarasi variabel. Kemudian di proses kondisi awal yang menghasilkan keluaran yaitu buzzer tidak berbunyi, servo tidak berjalan. Pada alat ini digunakan sensor berat untuk berat muatan, dan saklar berperan utama dari alat tersebut, untuk memulai alat yang akan untuk dijalankan. Apabila saklar sudah di aktifkan maka motor servo akan aktif, dan sensor berat mendeteksi berat muatan, maka buzzer berbunyi jika berat muatan melebihi berat yang ditentukan.

\subsection{Perancangan Program Arduino}

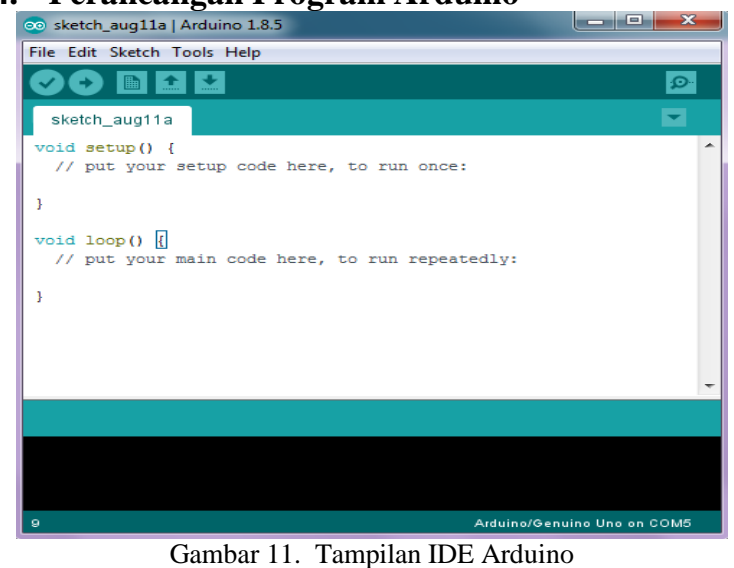

Gambar 11. Tampilan IDE Arduino 
Pada alat pendeteksi berat muatan bus Transjakarta ini dibutuhkan pemograman mikrokontroler agar alat tersebut dapat bekerja sesuai dengan prinsip kerja alat. Langkah pertama yang dilakukan yaitu membuka aplikasi IDE Arduino dengan tampilan awal seperti gambar 11.

Setelah membuka aplikasi IDE Arduino, langkah selanjutnya yaitu menuliskan sketch program pada lembar kerja yang telah tersedia. Berikut ini adalah sketch program alat simulasi pendeteksi berat muatan pada Transjakarta sebagai berikut:

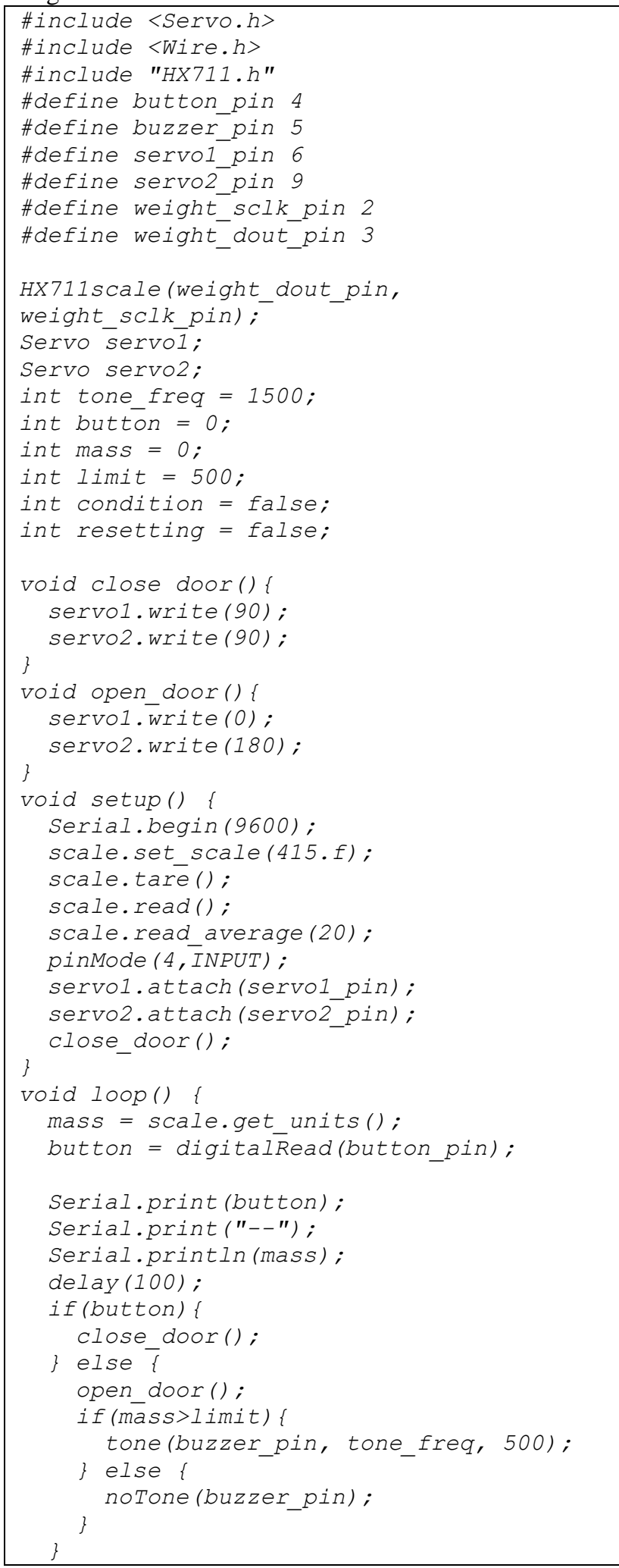

Setelah sketch program selesai dibuat, selanjutnya dilakukan compile program untuk memeriksa ada atau tidaknya kesalahan penulisan coding program

\subsection{Pengujian Teknis Alat}

Uji teknis adalah pengujian komponen menggunakan osiloskop digital untuk mengetahui gelombang pada sensor berat. Uji teknis ini dilakukan pada sensor berat, buzzer. Serta mengukur menggunakan osiloskop digital untuk melihat gelombang yang ada pada sensor berat. Hasil gelombang sensor berat dapat dilihat pada gambar 12 dan 13 .
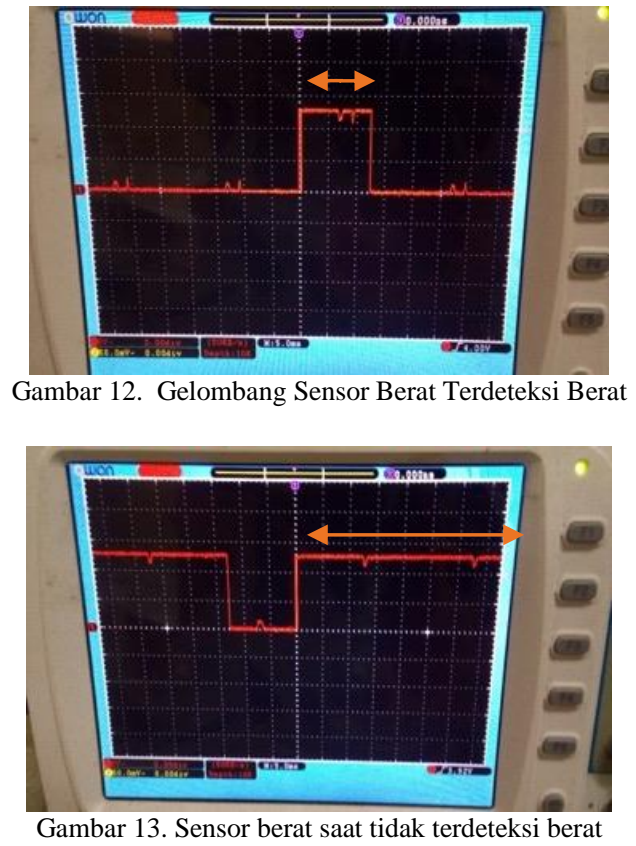

Pengujian kedua adalah pengujian buzzer ketika terhubung dengan mikrokontroler Arduino Uno, untuk melakukan uji coba pada buzzer menggunakan multimeter digital. Hasil uji coba pada buzzer menggunakan multimeter pada gambar 14 dan 15 .

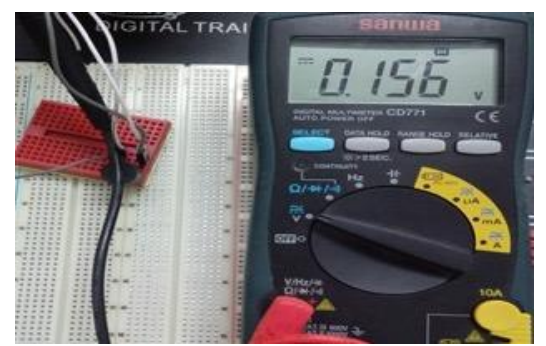

Gambar 14. Uji buzzer menggunakan multimeter saat LOW

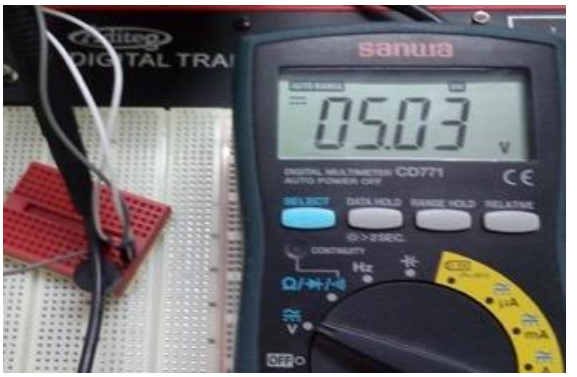

Gambar 15. Uji buzzer menggunakan multimeter saat HIGH

Yudi Irawan Chandra 
Pada saat alat Buzzer di uji terdapat terdeteksi nilai tegangan dengan menggunakan multimeter. Dapat melihat hasil uji pada buzzer tabel 1 .

\begin{tabular}{lll}
\multicolumn{2}{c}{ TABEL 1 . HASIL UJI COBA PADA BUZZER } \\
\hline Kondisi Buzzer & Tegangan & Keterangan \\
\hline LOW $(0)$ & $0.156 \mathrm{~V}$ & Tidak Bunyi \\
HIGH $(5)$ & $5.03 \mathrm{~V}$ & Bunyi \\
\hline
\end{tabular}

Pengujian ketiga adalah pengujian switch ketika terhubung dengan mikrokontroler Arduino Uno, untuk melakukan uji coba pada switch menggunakan multimeter digital. Hasil uji coba pada switch menggunakan multimeter pada gambar 16 dan 17.

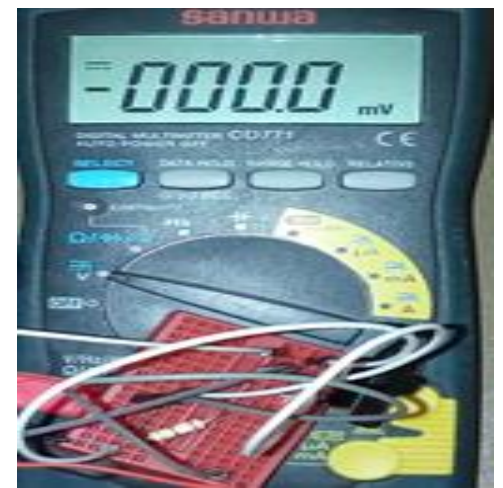

Gambar 16. Uji switch menggunakan multimeter saat LOW

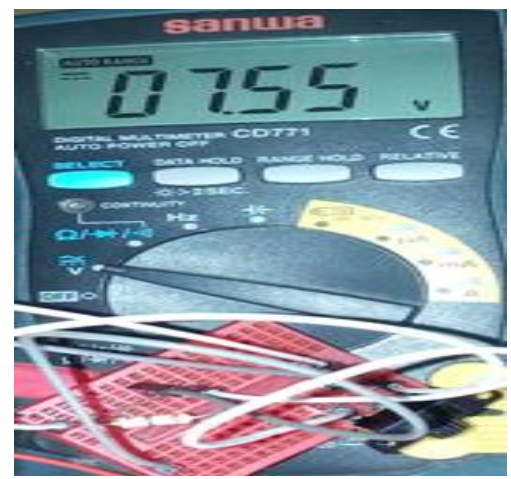

Gambar 17. Uji switch menggunakan multimeter saat HIGH

Pada saat alat switch di uji terdapat terdeteksi nilai tegangan dengan menggunakan multimeter. Dapat melihat hasil uji pada switch tabel 2.

TABEL 2. HASIL UJI COBA PADA SWITCH

\begin{tabular}{lll}
\hline Kondisi Buzzer & Tegangan & Keterangan \\
\hline LOW $(0)$ & $0 \mathrm{mV}$ & Tidak Beroperasi \\
HIGH $(12)$ & $7.55 \mathrm{~V}$ & Beroperasi \\
\hline
\end{tabular}

Pengujian terakhir adalah pengujian motor servo ketika terhubung dengan mikrokontroler Arduino Uno, untuk melakukan uji coba pada motor servomenggunakan osiloskop. Hasil uji coba pada motor servo 1 dan 2 posisi awal $90^{\circ}$ dengan skala horizontal $1 \mathrm{~ms}$, memiliki tinggi gelombang atau tegangan puncak ke puncak (Vpp) sebesar $5.28 \mathrm{~V}$, maka periode $20.02 \mathrm{~ms}$, dan frekuensi sebesar $49.94 \mathrm{~Hz}$ dengan menggunakan osiloskop pada gambar 18 dan dengan skala horizontal $5 \mathrm{~ms}$, memiliki tinggi gelombang atau tegangan puncak ke puncak (Vpp) sebesar $5.52 \mathrm{~V}$, maka periode $20.02 \mathrm{~ms}$, dan frekuensi sebesar $49.94 \mathrm{~Hz}$ dengan menggunakan osiloskop pada gambar 19.

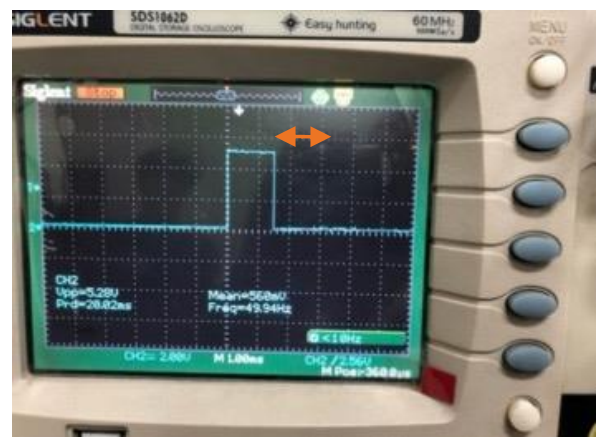

Gambar 18. Uji motor servo posisi $90^{\circ}$ dengan skala horizontal $1 \mathrm{~ms}$

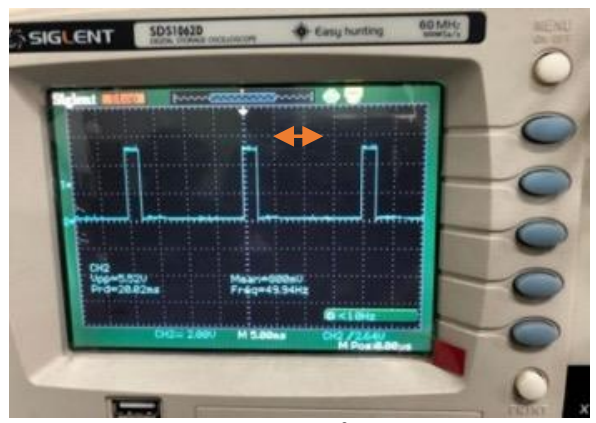

Gambar 19. Uji motor servo posisi $90^{\circ}$ dengan skala horizontal $5 \mathrm{~ms}$

Pada gambar 20 Hasil uji coba pada motor servo1 posisi $0^{0}$ dengan skala horizontal $1 \mathrm{~ms}$, memiliki tinggi gelombang atau tegangan puncak ke puncak (Vpp) sebesar $5.36 \mathrm{~V}$, maka periode $20.02 \mathrm{~ms}$, dan frekuensi sebesar $49.96 \mathrm{~Hz}$ dengan menggunakan osiloskopdan dengan skala horizontal $5 \mathrm{~ms}$, memiliki tinggi gelombang atau tegangan puncak ke puncak (Vpp) sebesar $5.36 \mathrm{~V}$, maka periode $20.02 \mathrm{~ms}$, dan frekuensi sebesar $49.96 \mathrm{~Hz}$ dengan menggunakan osiloskop pada gambar 21 .

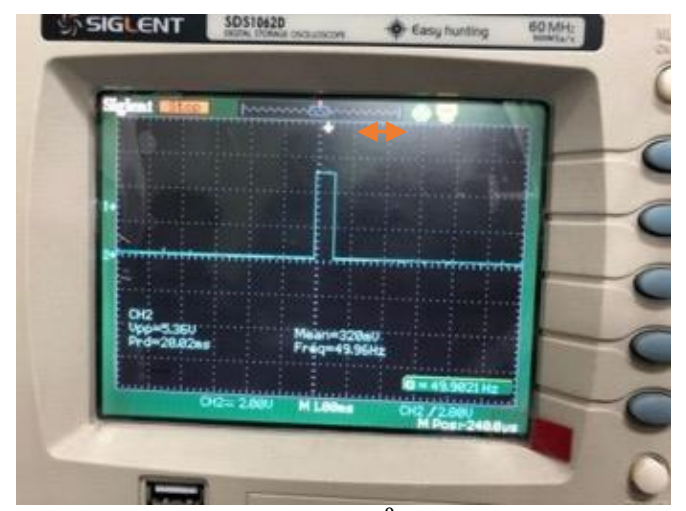

Gambar 20. Uji motor servo1 posisi $0^{0}$ dengan skala horizontal $1 \mathrm{~ms}$

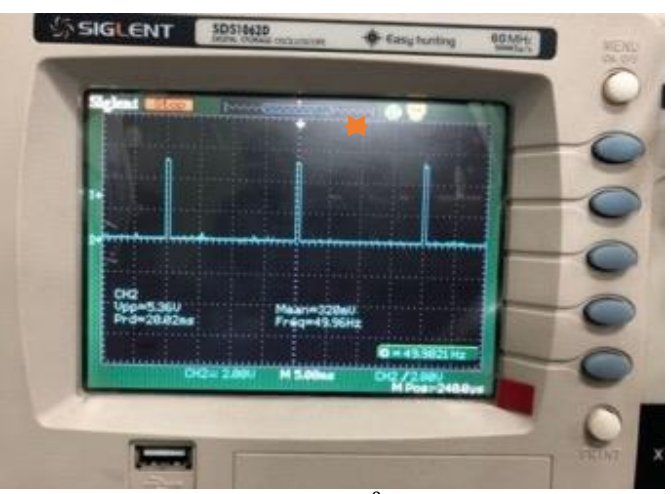

Gambar 21. Uji motor servo1 posisi $0^{0}$ dengan skala horizontal $5 \mathrm{~ms}$ 
Pada gambar 22 Hasil uji coba pada motor servo2 posisi $180^{\circ}$ dengan skala horizontal $1 \mathrm{~ms}$, memiliki tinggi gelombang atau tegangan puncak ke puncak (Vpp) sebesar $5.52 \mathrm{~V}$, maka periode $20.02 \mathrm{~ms}$, dan frekuensi sebesar $49.94 \mathrm{~Hz}$ dengan menggunakan osiloskop dan dengan skala horizontal $5 \mathrm{~ms}$, memiliki tinggi gelombang atau tegangan puncak ke puncak (Vpp) sebesar $5.28 \mathrm{~V}$, maka periode $20.02 \mathrm{~ms}$, dan frekuensi sebesar $49.94 \mathrm{~Hz}$ dengan menggunakan osiloskop pada gambar 23 .

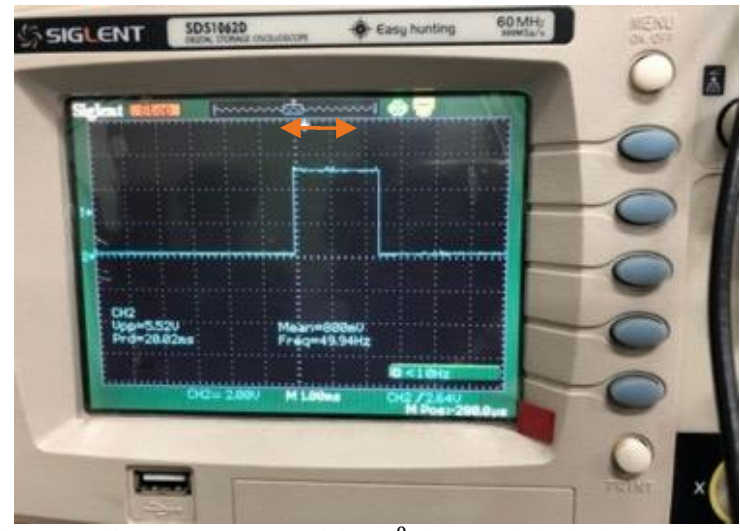

Gambar 22. Uji motor servo2 posisi $180^{\circ}$ dengan skala horizontal $1 \mathrm{~ms}$

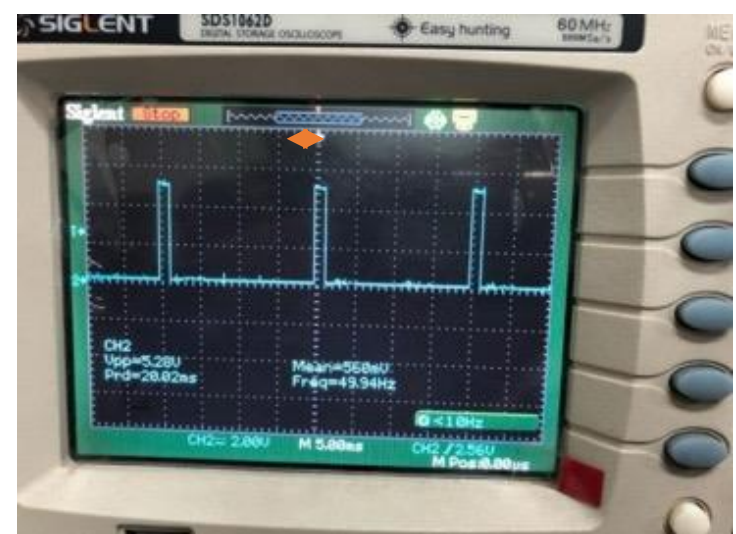

Gambar 23. Uji motor servo2 posisi $180^{\circ}$ dengan skala horizontal $5 \mathrm{~ms}$

Dari data yang diperoleh dari gambar 18, 20 dan 22, melalui pengujian motor servo menggunakan osiloskop, maka dapat diketahui pada saat motor servo tidak bergerak karena switch tidak di jalankan atau posisi awal $90^{\circ}$ dengan skala horizontal $1 \mathrm{~ms}$, memiliki tinggi gelombang atau tegangan puncak ke puncak (Vpp) sebesar 5.28 V, maka periode 20.02 ms, dan frekuensi sebesar $49.94 \mathrm{~Hz}$, sedangkan pada saat motor servo1 bergerakkarena switch di jalankan menjadi posisi awal $0^{0}$ dengan skala horizontal $1 \mathrm{~ms}$, memiliki tinggi gelombang atau tegangan puncak ke puncak (Vpp) sebesar $5.36 \mathrm{~V}$, maka periode $20.02 \mathrm{~ms}$, dan frekuensi sebesar 49.96 $\mathrm{Hz}$, dan motor servo2 bergerak karena switch di jalankan menjadi posisi awal $180^{\circ}$ dengan skala horizontal $1 \mathrm{~ms}$, memiliki tinggi gelombang atau tegangan puncak ke puncak (Vpp) sebesar 5.52 V, maka periode $20.02 \mathrm{~ms}$, dan frekuensi sebesar $49.94 \mathrm{~Hz}$. Perhitungan untuk menghitung Duty Cycle dengan menggunakan rumus (2).

$$
\mathrm{D}=\frac{\text { Ton }}{\text { (Ton-Toff) }} \mathrm{X} 100 \%
$$

Penjelasan:

$\mathrm{D}=$ Duty Cycle

Ton = Waktu dimana tegangan keluaran berada pada posisi tinggi (High atau1)

Toff $=$ Waktu dimana tegangan keluaran berada pada posisi rendah (Low atau0)

$\mathrm{T}=$ Periode satu gelombang

Berdasarkan rumus tersebut dapat dilakukan penghitungan untuk gelombang motor servo $0^{\circ}, 90^{\circ}$, dan $180^{\circ}$ sebagai berikut:

$$
\begin{array}{ll}
\text { A. Gelombang Motor Servo Posisi } 0^{0} \\
\text { Ton } & =0,4 \mathrm{~ms} \\
\mathrm{~T} & =20,02 \mathrm{~ms} \\
\mathrm{D} & =\frac{\text { Ton }}{\mathrm{T}} \times 100 \% \\
\mathrm{D} & =\frac{0,4}{20,02} \times 100 \% \\
\mathrm{D} & =0,02 \times 100 \% \\
\mathrm{D} & =2 \%
\end{array}
$$

Maka besaran Duty Cycle yang diperoleh motor servo posisi $0^{0}$ yaitu sebesar: $2 \%$

$$
\begin{array}{ll}
\text { B. Gelombang Motor Servo Posisi } 90^{\circ} \\
\text { Ton } & =1,4 \mathrm{~ms} \\
\mathrm{~T} & =20,02 \mathrm{~ms} \\
\mathrm{D} & =\frac{\text { Ton }}{\mathrm{T}} \times 100 \% \\
\mathrm{D} & =\frac{1,4}{20,02} \times 100 \% \\
\mathrm{D} & =0,07 \times 100 \% \\
\mathrm{D} & =7 \%
\end{array}
$$

Maka besaran Duty Cycle yang diperoleh motor servo posisi $90^{\circ}$ yaitu sebesar: $7 \%$

$$
\begin{array}{ll}
\text { C. Gelombang Motor Servo Posisi } 180^{\circ} \\
\text { Ton } & =2,2 \mathrm{~ms} \\
\mathrm{~T} & =20,02 \mathrm{~ms} \\
\mathrm{D} & =\frac{\text { Ton }}{\mathrm{T}} \times 100 \% \\
\mathrm{D} & =\frac{2,2}{20,02} \times 100 \% \\
\mathrm{D} & =0,11 \times 100 \% \\
\mathrm{D} & =11 \%
\end{array}
$$

Maka besaran Duty Cycle yang diperoleh motor servo posisi $180^{\circ}$ yaitu sebesar: $11 \%$

Pada saat alat motor servo di uji terdapat terdeteksi nilai tegangan, frekuensi, dan periode dengan menggunakan osiloskop. Dapat melihat hasil uji pada motor servo tabel 3.

\begin{tabular}{ccclll}
\multicolumn{5}{c}{ TABEL 3. HASIL UJI COBA PADA MOTOR SERVO } \\
\hline No & $\begin{array}{l}\text { Kompo } \\
\text { nen }\end{array}$ & Vpp(V) & $\begin{array}{l}\text { Periode } \\
(\mathbf{m s})\end{array}$ & $\begin{array}{l}\text { Frekuensi } \\
(\mathbf{H z})\end{array}$ & $\begin{array}{l}\text { Kete } \\
\text { rangan }\end{array}$ \\
\hline 1 & & $5,36 \mathrm{~V}$ & $\begin{array}{l}20,02 \\
\mathrm{~ms}\end{array}$ & $49,96 \mathrm{~Hz}$ & $0^{\circ}$ \\
2 & $\begin{array}{l}\text { Motor } \\
\text { Servo }\end{array}$ & $5,28 \mathrm{~V}$ & $\begin{array}{l}20,02 \\
\mathrm{~ms}\end{array}$ & $49,94 \mathrm{~Hz}$ & $90^{\circ}$ \\
3 & & $5,52 \mathrm{~V}$ & $\begin{array}{l}20,02 \\
\mathrm{~ms}\end{array}$ & $49,94 \mathrm{~Hz}$ & $180^{\circ}$ \\
\hline
\end{tabular}

Tabel 4 merupakan tabel hasil uji coba keseluruhan dari rangkaian alat pendeteksi muatan berat pada Transjakarta berbasis mikrokontroler Arduino Uno. 
TABEL 4. HASIL UJI COBA KESELURUHAN

\begin{tabular}{|c|c|c|c|c|c|}
\hline No & Kejadian & Switch & Motor Servo & $\begin{array}{l}\text { Modul } \\
\text { Sensor } \\
\text { Berat }\end{array}$ & Buzzer \\
\hline 1 & $\begin{array}{l}\text { Terdeteksi } \\
\text { Switch Di } \\
\text { Aktifkan }\end{array}$ & $\begin{array}{c}\text { Switch Aktif } \\
\text { (1-High) }\end{array}$ & $\begin{array}{c}\text { Motor Servol } \\
\text { (Bergerak } \\
180^{\circ} \text { ) } \\
\text { Motor Servo2 } \\
\text { (Bergerak } 0^{\circ} \text { ) }\end{array}$ & $\begin{array}{c}\text { Sensor } \\
\text { Berat } \\
\text { Mendeteksi } \\
\text { (1- High) }\end{array}$ & $\begin{array}{c}\text { Mati } \\
(0-\text { Low })\end{array}$ \\
\hline 2 & $\begin{array}{c}\text { Terdeteksi } \\
\text { Beban } \\
\text { Melebihi } \\
\text { Berat } \\
\text { Muatan }\end{array}$ & $\begin{array}{c}\text { Switch Aktif } \\
\text { (1-High) }\end{array}$ & $\begin{array}{l}\text { Motor Servol } \\
\text { (Bergerak } \\
180^{\circ} \text { ) } \\
\text { Motor Servo2 } \\
\text { (Bergerak } 0^{\circ} \text { ) }\end{array}$ & $\begin{array}{c}\text { Sensor } \\
\text { Berat } \\
\text { Mendeteksi } \\
\text { (1- High) }\end{array}$ & $\begin{array}{l}\text { Menyala } \\
\text { (1 - High) }\end{array}$ \\
\hline 3 & $\begin{array}{c}\text { Terdeteksi } \\
\text { Beban } \\
\text { Tidak } \\
\text { Melebihi } \\
\text { Berat } \\
\text { Muatan }\end{array}$ & $\begin{array}{c}\text { Switch Aktif } \\
\text { (1-High) }\end{array}$ & $\begin{array}{l}\text { Motor Servol } \\
\text { (Bergerak } \\
180^{\circ} \text { ) } \\
\text { Motor Servo2 } \\
\text { (Bergerak } 0^{\circ} \text { ) }\end{array}$ & $\begin{array}{c}\text { Sengor } \\
\text { Berat } \\
\text { Mendeteksi } \\
\text { (1- High) }\end{array}$ & $\begin{array}{c}\text { Mati } \\
(0-\text { Low })\end{array}$ \\
\hline 4 & $\begin{array}{l}\text { Terdeteksi } \\
\text { Switch Di } \\
\text { Non } \\
\text { Aktifkan }\end{array}$ & $\begin{array}{c}\text { Switch Aktif } \\
\text { (0-Low) }\end{array}$ & $\begin{array}{c}\text { Motor Servol } \\
\text { (Bergerak } \\
\left.90^{\circ}\right) \\
\text { Motor Servo2 } \\
\text { (Bergerak } \\
\left.90^{\circ}\right)\end{array}$ & $\begin{array}{c}\text { Sensor } \\
\text { Berat } \\
\text { Tidak } \\
\text { Mendeteksi } \\
\text { (0- Low) }\end{array}$ & $\begin{array}{c}\text { Mati } \\
(0-\text { Low })\end{array}$ \\
\hline
\end{tabular}

\section{KESIMPULAN}

Dari hasil pengujian yang telah dilakukan terhadap Purwarupa Alat Pendeteksi Berat Muatan berbasis Mikrokontroler Arduino Uno, maka dapat disimpulkan bahwa prototipe ini dapat digunakan untuk sistem pendeteksi berat muatan dengan di lengkapi input yang berupa switch, sensor berat, pemprosessan yang berupa Mikrokontroler Arduino Uno, dan output yang berupa buzzer, motor servo. Mikrokontroler Arduino Uno mendapatkan tegangan sebesar 5V ketika dihubungkan dengan catu daya. Hasil pengujian, alat ini dapat mendeteksi adanya berat muatan Transjakarta, kemudian buzzer akan berbunyi, dimana sensor berat mendeteksi adanya berat muatan. Sensor berat pada prototipe dan mendeteksi sampai berat muatan 200 gram.

Sistem Pendeteksi Berat Muatan Berbasis Mikrokontroler Arduino Uno dapat dikembangkan lagi dengan menambahkan komponen lainnya seperti LCD sebagai mengetahui data berat pada Transjakarta. Pengembangan lainnya adalah prototipe yang dihasilkan dapat diintegrasikan pada Transjakarta untuk mengembangkan sistem pada kendaraan.

\section{DAFTAR PUSTAKA}

[1] Heri Andrianto, Aan Darmawan, Arduino Belajar Cepat dan Pemrograman, Informatika, Bandung, 2015.

[2] Ardi Winoto, Mikrokontroler AVR Atmega 8/16/32/8535 dan Pemogramannya dengan Bahasa C pada WinAVR, Informatika, Bandung, 2010.

[3] Budiharto, Widodo, Perancangan Sistem dan Aplikasi Mikrokontroler, PT. Elex Media Komputindo, Jakarta, 2005.

[4] Abdul Kadir, From Zero A Pro Arduino, Penerbit Andi, Yogyakarta, 2015

[5] Mochamad Rozak, Fauzan Ismail, dkk, Sistem Peringatan Muatan Berlebihan Pada Truk, PI/KKP STMIK Jakarta STI\&K, Jakarta, 2017.

[6] Sulistyowati, Riny, Dwi Febriantoro, Perancangan Prototype Sistem Kontrol dan Monitoring Pembatas Daya Listrik Berbasis Mikrokontroler, Jurnal IPTEK Vol.16 No, 1 Mei 2012.

[7] Sujarwata, Pengendali Motor Servo Berbasis Mikrokontroler Basic Stamp 2SX Untuk Menggambarkan Sistem Robotika, Universitas Negeri Semarang (UNNES), Semarang, Volume V, Nomor 1, Mei 2013.

\section{BIODATA PENULIS}

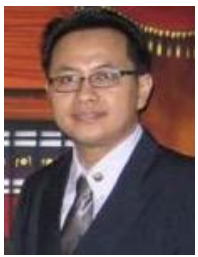

Yudi Irawan Chandra

Merupakan dosen tetap di STMIK Jakarta STI\&K pada Program Studi Sistem Informasi.

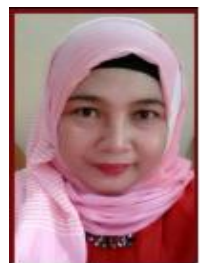

Kosdiana

Merupakan dosen tetap di STMIK Jakarta STI\&K pada Program Studi Sistem Komputer. 